\title{
HAEMODYNAMIC AND PLASMA VASOPRESSIN RESPONSES WITH HIGH-DOSE FENTANYL ANAESTHESIA DURING AORTO-CORONARY BYPASS OPERATIONS
}

\author{
L.A. Crone, N. Wilson, J. Ngsee, K.W. Turnbull and K. Leighton
}

\section{Abstract}

Twelve male patients were given high dose fentanyl $\left(75-100 \mu \mathrm{g} \cdot \mathrm{kg}^{-1}\right)$ anaesthesia with oxygen during elective aorto-coronary bypass operations, and their haemodynamic and vasopressin responses were determined during induction, sternotomy, cardiopulmonary bypass, post-bypass and recovery periods. For comparison, a group of 12 male patients were anaesthetized with morphine, halothane 0.5 per cent, nitrous oxide and oxygen, and were similarly studied.

Significant alterations in haemodynamics included increased mean arterial pressure after sternotomy in the fentanyl group, increased heart rate in both groups, increased systemic vascular resistance after sternotomy only in the halothane group, and decreased left ventricular stroke work index in both groups following induction, bypass, and during the recovery periods.

Plasma vasopressin levels increased significantly in both groups during the bypass period, but returned to baseline levels following bypass. Serum sodium and osmolality did not change significantly, and urinary sodium and potassium excretion rose with the progress of the operation in both groups. A positive correlation was found between mean arterial pressure and vasopressin only in the halothane group. Systernic vascular resistance was correlated to vasopressin levels in both groups.

Vasopressin response in both groups was similar, with significant but relatively low increases in levels during cardiopulmonary bypass. Fentanyl-oxygen anaesthesia did not provide haemodynamic stability in eight of 12 patients.

KEY WORDS: ANAESTHETICS, intravenous, fentanyl; HoRMONES, vasopressin, antidiuretic hormone; SURGERY, aortocoronary bypass.

\section{INTRODUCTION}

Although Remarkable haemodynamic stability has been reported in patients given high doses of fentanyl $\left(50-100 \mu \mathrm{g} \cdot \mathrm{kg}^{-1}\right)$ as the sole anaesthetic agent during both valvular and aortocoronary bypass operations ${ }^{1-4}$ one recent study refutes this claim. ${ }^{5}$ Haemodynamic instability during fentanyl anaesthesia could be a consequence of fluctuations in levels of plasma vaso-

L.A. Crone, M.D., \& K.W. Turnbull, M.D., F.R.C.P.(C), Department of Anaesthesia, Vancouver General Hospital, Vancouver, B.C.; N. Wilson, Ph.D., J. Ngsee, M.Sc., Department of Physiology, University of British Columbia, Vancouver, B.C. K. Leighton, M.B., F.R.C.P.(C), Department of Anaesthesia, Health Sciences Centre Hospital, University of British Columbia, Vancouver, B.C.

Reprints: L.A. Crone, M.D., Department of Anaesthesia, University Hospital, Saskatoon, Saskatchewan S7N OX0.

This study was supported by grants from the Medical Research Council of Canada and from the British Columbia Health Care Research Foundation. 525 pressin. Plasma vasopressin is a potent vasoconstrictor in hyperphysiological ranges $(>20 \mathrm{pg})$ $\mathrm{ml}$ ), acting on vascular smooth muscle, and thus could interfere further with the already compromised myocardial oxygen balance present in patients with atherosclerotic heart disease. ${ }^{6-12}$

The purpose of the present study was to determine the effects of high dose fentanyl on haemodynamic and vasopressin response during aortocoronary bypass operations and to compare these effects with our conventional anaesthetic technique.

\section{METHODS}

Twenty-four male patients between the ages of 40 and 70 years undergoing elective operations for aortocoronary bypass were studied. Twelve patients were randomly chosen to receive morphine $\left(0.5 \mathrm{mg} \cdot \mathrm{kg}^{-1}\right)$, halothane $(0.5-$ 1.0 per cent), nitrous oxide-oxygen anaesthesia. The remaining 12 patients were anaesthetized

Can. Anaesth. Soc. J., vol. 29, no. 6, November 1982 
with high dose fentanyl $\left(75-100 \mu \mathrm{g} \cdot \mathrm{kg}^{-1}\right)$ with oxygen. Informed consent was obtained from all patients. The study had been approved by the University's Committee for Human Research.

All patients were classed ASA III, had atherosclerotic heart disease and, with one exception, had normal left ventricular function and ejection fractions greater than 0.5 . All had normal renal function. Twenty were taking propranolol and all received their usual dose on the morning of operation.

Premedication consisted of a benzodiazepine $0.15 \mathrm{mg} \cdot \mathrm{kg}^{-1}$ by mouth, morphine $0.15 \mathrm{mg} \cdot \mathrm{kg}^{-1}$ intramuscularly and hyoscine $0.4 \mathrm{mg}$ intramuscularly sixty to ninety minutes before the operations.

Oxygen was administered by face mask while the following monitoring devices were inserted under local anaesthesia: two 16 gauge intravenous cannulae, a radial artery cannula and a 7 French Oximetric Shaw flow-directed thermodilution pulmonary artery optical catheter, model P71 10 (Oximetrix Inc., Mountain View, California), inserted through a Cordis sheath via an internal jugular vein. Electrocardiograph leads were applied and, following induction of anaesthesia, an oesophageal temperature probe and a Foley catheter were inserted. Fentanyl $25 \mu \mathrm{g} \cdot \mathrm{kg}^{-1}$ was administered slowly, ventila. tion was assisted as required, and succinylcholine $1.5 \mathrm{mg} \cdot \mathrm{kg}^{-1}$ or pancuronium $0.1 \mathrm{mg} \cdot \mathrm{kg}^{-1}$ was used to facilitate tracheal intubation. An additional $25-75 \mu \mathrm{g} \cdot \mathrm{kg}^{-1}$ of fentanyl was given before incision. Respirations were controlled and paralysis was maintained with pancuronium. Postoperatively patients were ventilated until the following morning. Narcotic antagonists were not administered postoperatively and muscle relaxants were not reversed. Plasmalyte was used for the pump prime in both groups.

Blood samples were collected from all patients in the following sequence:

(1) afternoon of the pre-operative day

(2) pre-induction

(3) post-induction (anaesthesia response following tracheal intubation)

(4) post-sternotomy (surgical response)

(5) cardiopulmonary bypass at 15 minutes (early bypass response)

(6) cardiopulmonary bypass at 30 minutes (late bypass response)

(7) post-bypass (patient stabilized)

(8) post-anaesthetic room (recovery period). At each of these times multiple haemodynamic measurements were made. Cardiac output was determined in triplicate by the thermodilution technique. Cardiac index, systemic vascular resistance, pulmonary vascular resistance, left ventricular stroke work index, rate pressure product, and triple index were calculated. Blood samples were drawn for serum electrolytes, osmolality, plasma vasopressin and arterial blood gases. Blood samples for arginine vasopressin measurements were collected in EDTA tubes and placed on ice. Plasma was separated by centrifuging within one hour and stored at $-20^{\circ} \mathrm{C}$ for a period not exceeding three weeks until radioimmunoassay. The vasopressin values reported here have been corrected for extraction loss. Urine samples were obtained starting with sample time 3. Initial residual urine obtained following insertion of the Foley catheter was discarded, urine flow was calculated, and urine osmolality and electrolytes were measured. Arginine vasopressin was measured following extraction of plasma with organic solvents, ${ }^{13}$ using a previously described radioimmunoassay system. ${ }^{14}$

Statistical analyses included student's paired t-test for comparison of means within groups, and between the two groups. $P$ values less than 0.05 were considered significant. Correlation analysis was done.

Results are expressed as mean \pm standard error of the mean.

\section{RESUlts}

The mean fentanyl dose administered was $93.3 \mu \mathrm{g} \cdot \mathrm{kg}^{-1}$. Marked skeletal muscle rigidity was observed in all patients in the fentanyl group and was overcome with pancuronium or succinylcholine before completion of the infusion of $25 \mu \mathrm{g} \cdot \mathrm{kg}^{-1}$ of fentanyl. Interviews conducted three to four days after operation revealed no recall in any of the 24 patients.

Mean age of the halothane subjects was $55 \pm$ 2 years and of the fentanyl group $57 \pm 2$ years. Bypass time was $122 \pm 17 \mathrm{~min}$ and $156 \pm 14$ min respectively. Aortic cross-clamp time was $80 \pm 12 \mathrm{~min}$ for the halothane group and $88 \pm$ 9 min for the fentanyl group. Subjects in the halothane group lost $900 \pm 190 \mathrm{ml}$ of blood and those in the fentanyl group $1200 \pm 170 \mathrm{ml}$. Data are recorded in Tables I to IV inclusive.

Heart rate increased significantly in both groups. Mean arterial pressure increased significantly from $90 \pm 9$ torr to $106 \pm 19$ tor following incision and sternotomy in the fentanyl group, but returned to preinduction levels 

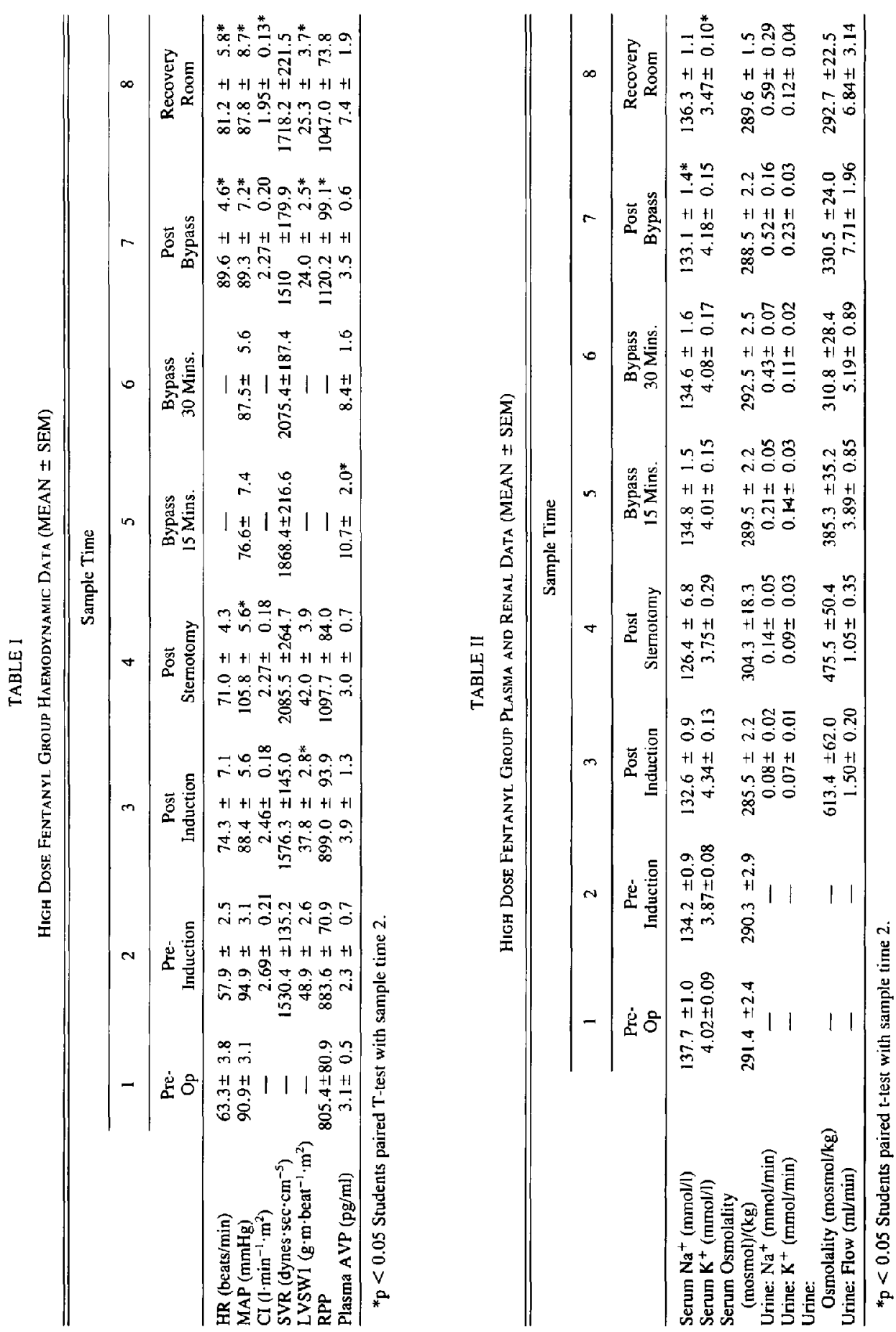

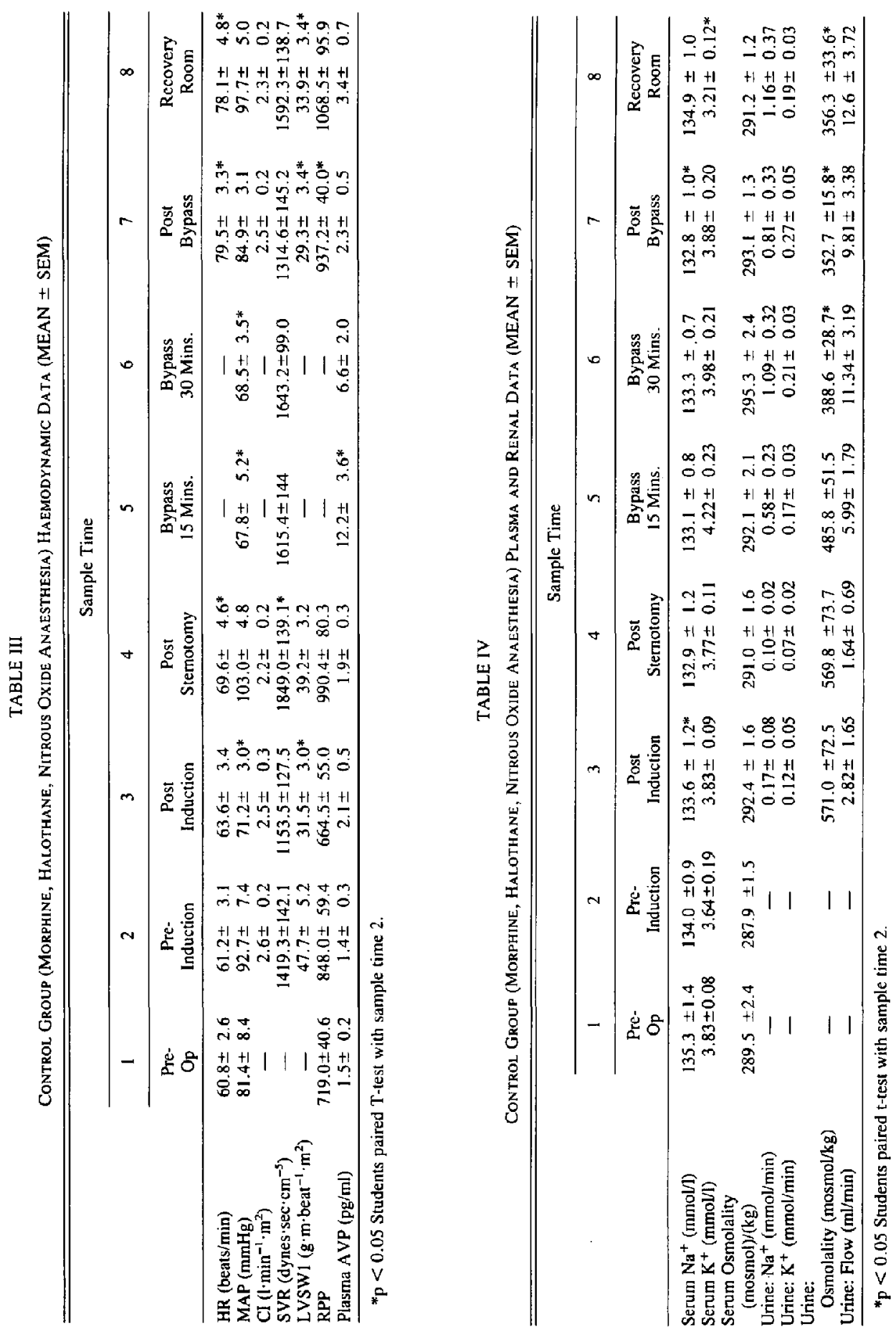
for the remainder of the procedure (Table I). However, between and at the study times, eight of the 12 fentanyl patients required vasodilators (sodium nitroprusside or phentolamine) to maintain pressures within an acceptable range, and propranolol was administered to three patients, two of whom had not been on the drug preoperatively, to decrease the heart rate. Six of the halothane patients required vasodilators to decrease blood pressure.

Systemic vascular resistance increased in the halothane group from a pre-induction value of $1419 \pm 42$ to a high of $1849 \pm$ dynes $\cdot \mathrm{sec} \cdot \mathrm{cm}^{-5}$ after sternotomy, then decreased to preinduction values. Cardiac index decreased significantly in the fentanyl subjects to $1.95 \mathrm{l} \cdot \mathrm{min}^{-1} / \mathrm{m}^{2}$ in the recovery room. Left ventricular stroke work index decreased significantly in both groups post-induction, post-bypass, and in the recovery phase.

Plasma vasopressin concentration remained at basal levels $(1-2 \mathrm{pg} / \mathrm{ml})$ throughout the induction of anaesthesia and following sternotomy in both groups of subjects, (Tables I \& III). Elevated levels of this hormone were found in both groups during bypass (up to $12 \mathrm{pg} / \mathrm{ml}$ ) with higher levels in the early bypass period. In the fentanyl group, plasma arginine vasopressin again increased to $7 \mathrm{pg} / \mathrm{ml}$ during the recovery period.

Serum osmolality and sodium did not change significantly in either group. A significant decrease in serum potassium became evident only in the recovery phase of both groups.

Urinary sodium and potassium excretion rose with the progress of the operation in both groups of subjects. However, the increase in potassium excretion was smaller in the fentanyl as compared to the halothane group.

Correlation analysis was done using sample times 5 and 6 (high vasopressin period), attempting to correlate changes in vasopressin levels with cardiovascular parameters. Positive correlation was found between mean arterial pressure and vasopressin only in the halothane group. Systemic vascular resistance was correlated to vasopressin levels in both groups. F-tests of slopes of vasopressin versus mean arterial pressure and systemic vascular resistance revealed no significant difference between the halothane and the fentanyl groups.

\section{Discussion}

This study does not support the contention of others that haemodynamic parameters remain stable during high dose fentanyl anaesthesia for aortocoronary bypass procedures. Furthermore, in this study vasopressin levels during cardiopulmonary bypass remained below the hyperphysiological levels previously reported using this anaesthetic technique, ${ }^{\prime}$ and halothane and morphine technique. ${ }^{6-12}$ Six out of 24 patients in our study did not have any elevation of the circulating levels of arginine vasopressin during cardiopulmonary bypass. Our data did not demonstrate significant differences between the two anaesthetics used with respect to plasma arginine vasopressin concentrations. Most patients showed a tendency for arginine vasopressin levels to return toward basal values with the second cardiopulmonary bypass sample, indicating only a transient stimulus. The nature of the stimulus, however, remains open to conjecture. Plasma vasopressin might be released in response to changes in blood pressure, volume and distribution, ${ }^{15}$ to pain, ${ }^{16}$, stress, ${ }^{17}$ temperature fluctuations, ${ }^{18}$ and drugs including morphine. ${ }^{19}$ Most of these stimuli result in vasopressin elevation within the physiological (that is osmoregulatory) limits for this hormone from basal levels averaging $2 \mathrm{pg} / \mathrm{ml}$ to highs of $20 \mathrm{pg} / \mathrm{ml}$. However, increases of five to ten times above the upper physiological limit for arginine vasopressin have been reported during cardiac operations, particularly coronary artery bypass procedures. ${ }^{10}$ These elevations were not accompanied by changes in plasma osmolality, electrolytes or blood pressure. ${ }^{1,7,8,10}$ In other experiments, elevation of circulating plasma vasopressin has been observed in response to vagal cooling in the dog. ${ }^{14}$ Thus the stimulus to vasopressin release during cardiopulmonary bypass might be sought in the induction of cooling while on bypass or with the use of cold cardioplegia.

A direct comparison of the vasopressin data cited in these various reports is difficult, partly because of the differences in surgical and anaesthetic procedures used, partly due to the heterogeneity of patient groups and also because of the vasopressin measurements themselves. Although the studies employed the same extraction procedure before radio-immunoassay, ${ }^{13}$ the extraction recoveries were not reported ${ }^{1}$ and the method of calculation applied to obtain these figures was not stated. ${ }^{10}$

In view of the fact that persistent vasopressin elevation might constitute a hazard to cardiovascular stability, ${ }^{20}$ further studies into the iden- 
tification and isolation of the stimulus responsible for the increase of vasopressin during cardiopulmonary bypass might prove beneficial.

Despite baseline levels of vasopressin before cardiopulmonary bypass, the haemodynamic parameters were not stable in the fentanyl group. Eight of the 12 patients in this group exhibited marked elevations in mean arterial pressure after stemotomy and while on bypass which necessitated use of vasodilators (either sodium nitroprusside or phentolamine), despite the use of a high mean dose of fentanyl $\left(93.3 \mu \mathrm{g} \cdot \mathrm{kg}^{-1}\right)$ before incision compared to that of other studies. ${ }^{1-3}$

The tables depict a relatively stable mean arterial pressure only because of the use of these vasodilating agents between and at sampling periods. Positive inotropic and chronotropic agents (dopamine and neosynephrine) were required in six of the eight fentanyl patients coming off bypass.

Although the pathophysiology of the haemodynamic changes observed in the fentanyl group is difficult to determine, such factors as inadequate depth of anaesthesia, dilution of the plasma fentanyl concentrations by the bypass priming solution, or increased catecholamines during bypass, especially elevated norepinephrine levels, might be operative..$^{21-23}$ In our study there was no correlation between the plasma arginine vasopressin levels and mean arterial pressures, nor were the levels of arginine vasopressin hyperphysiological. Thus, elevation of arginine vasopressin is an unlikely cause for the observed haemodynamic instability.

Non-pulsatile flow during cardiopulmonary bypass is a well-documented stress factor initiating marked elevation of plasma arginine vasopressin in other studies. ${ }^{6-11}$ The use of pulsatile flow during cardiopulmonary bypass is reported to attenuate this hormonal response. ${ }^{11,12}$ Nonpulsatile flow was used in our study, but vasopressin levels remained within the physiological range.

To summarize, fentanyl alone had no effect on plasma arginine vasopressin and successfully blocked the stress response to tracheal intubation and surgical stimulation. During cardiopulmonary bypass, vasopressin levels increased significantly but remained much lower than levels reported for both high-dose fentanyl ${ }^{\prime}$ and for morphine anaesthesia. ${ }^{6-8}$ High dose fentanyl might, in fact, have substantially blocked the hormonal stress response of non-pulsatile flow. Despite the elevated levels of vasopressin ob- served in the recovery room, these values are far below the hyperphysiological range $(>20$ $\mathrm{pg} / \mathrm{ml}$ ). Thus any hypertension observed must have been due to factors other than elevated vasopressin levels.

As a pure anaesthetic technique, high dose fentanyl has some disadvantages. Skeletal muscle rigidity does occur and might interfere with ventilation, ${ }^{5,25}$ although with early use of muscle relaxants this can be overcome. Prolonged respiratory depression, ${ }^{26,27}$ and awareness during operation have been reported. ${ }^{28,29}$ In eight of twelve patients given high doses of fentanyl, haemodynamic instability necessitated frequent interventions to ensure optimum myocardial oxygen balance. Our study population was comprised of patients with atherosclerotic heart disease whose left ventricular function was normal, a population which seems to behave quite differently from those recently reported.

High-dose fentanyl appears to be a useful induction agent, but in certain groups of patients, such as ours, lacks the necessary qualities of a "maintenance" agent. We urge others to beware of possible rapid fluctuations in haemodynamic variables, and suggest that the use of adjuvants such as nitrous oxide and vasodilators might be required to maintain an acceptable level of haemodynamic stability during aortocoronary bypass operations.

\section{ACKNOWLEDGEMENTS}

We wish to thank Mr. R. Tomusiak and Dr. T. Rodgers, University of British Columbia for their aid in statistical analysis.

Appreciation is extended to Mrs. Flo Welch for secretarial assistance.

\section{REFERENCES}

1. Stanley, T.H., Philbin, D.M \& Coggins, C.H. Fentanyl-Oxygen anaesthesia for coronary artery surgery: Cardiovascular and antidiuretic hormone response. Can. Anaesth. Soc. J. 26: 168 (1979).

2. Stanley, T.H. \& Webster, L.R.: Anacsthetic requirements and cardiovascular effects of Fentanyl-Oxygen and Fentanyl-Diazepam-Oxygen anaesthesia in man. Anaesth. Analg. 57:411 (1978).

3. Lunn, J.K., Stanley, T.H. Eisele, J., WebSTER, L. \& WoodWard, A. Plasma fentany] concentrations and influence of nitrous oxide on cardiovascular responses. Anestr. Analg. 58: 390 (1979)

4. Quinton, L., Whalley, D.G., Wynands, J.E., Morin, J.E. \& Burke, J. High dose 
fentanyl anaesthesia with oxygen for aortocoronary bypass surgery. Can. Anaesth. Soc. J. 28: 314 (1981).

5. Waller, J.L., Hug, C.C., Nagi.e, D.M. \& CRAVER, J. Fentanyl-Oxygen "Anaesthesia" and coronary bypass surgery. Anesth. Analg. (Abstr.) 59: 562 (1980).

6. Simpson, P. \& Forsling, M. The effects of halothane on plasma vasopressin during cardiopulmonary bypass. Clin. Endocrinol. 7: 33 (1977).

7. Philbin, D.M., Coggins, C.H., Wilson, N.\& SoKOLOSKI, J. Antidiuretic hormone levels during cardiopulmonary bypass. J. Thorac. Cardiovase. Surg. 73: 145 (1977)

8. Philbin, D.M. \& Coggins, C.H. Plasma antidiuretic hormone levels in cardiac surgical patients during morphine and halothane anaesthesia. Anesthesiology 49: 95 (1978).

9. Philbin, D.M., Coggins, C.H., Emerson, C.W., Levine, F.H. \& Buckley, M.J. Plasma vasopressin levels and urinary sodium excretion during cardiopulmonary bypass - comparison of halothane and morphine anesthesia. J. Thorac. and Cardiovasc. Surg. 77: 582 (1979)

10. Wu, W., ZbuzeK, V.K. \& Bellevue, C. Vasopressin release during cardiac operation. $\mathrm{J}$. Thorac. Cardiovasc. Surg. 79: 83 (1980).

11. Philbin, D.M., Levine, F.H., Emerson, C.W., Coggins, C.H., BuckLey, M.J. \& AusTEN, W.G. Plasma vasopressin levels and urinary flow during cardiopulmonary bypass in patients with valvular heart disease. Effect of pulsatile flow. J. Thorac. Cardiovasc. Surg. 78 779 (1979)

12. Philbin, D.M. \& Coggins, C.H. The effect of anaesthesia on antidiuretic hormone levels. In Endocrinology in Anaesthesia and Surgery. Edited by Stoeckel, H and Oyama T, Springer Verlag, 1980, pp 39.

13. Robertson, G.L., Myer, E.A., Athar, S. \& SINHA, T. Development and clinical application of a new method for the radioimmunoassay of arginine vasopressin in human plasma. J. Clin. Invest. 52: 2340 (1973).

14. Ledsome, J.R., Wilson, N. \& NGSEe, J. Rate of change of plasma vasopressin in response to atrial distention. Fed. Proced. In press 1982

15. Schrier, R.W., Berl, T. \& Anderson, R.J Osmotic and non-osmotic control of vasopressin release. Am. J. Physiol. 235 (4) F 321 (1979)

16. Kendler, K.S., Weitzman, R.E. \& Fisher, $D$.A. The effect of pain on plasma arginine vasopressin concentration in man. Clin. Endocrinol. 8: 89 (1978).

17. Husain, M.K., Manger, W.M., Rock, T.W., WEISS, R.J. \& FRANTZ, A.G. Vasopressin release due to manual restraint in the rat: Role of Body Compression and Comparison with other Stressful Stimuli. Endocrin. 104: 641 (1979).

18. Kasting, N.W., Veale, W.L. \& Cooper, K.E. Convulsive and Hypothermic Effects of Vasopressin the Brain of the Rat. Can. J. Physiol. Pharmacol. 58: 316 (1980).

19. DE WIED, D. \& GisPEN, W.H. Impaired Development of Tolerance to Morphine Analgesia in Rats with Hereditary Diabetes Insipidus. Psychopharmacol. (Berlin) 46: 27 (1976).

20. Wilson, M.F., Bracket, D.J., Archer, L.T. \& Hinshaw, L.B. Mechanisms of impaired cardiac function by vasopressin. Ann. Surg. 19I: 494 (1980).

21. Stanley, T.H., Berman, L., Green, O. \& RoberTSON, D. Plasma catecholamine and cortisol responses to fentanyl-oxygen anaesthesia for coronary-artery operation. Anesth. 53: 250 (1980).

22. Hoar, P.F., Stone, J.G., Faltas, A.N., BenDIXEN, H.H., Head, R.J. \& Berkowitz, B.A. Hemodynamic and adrenergic responses to anaesthesia and operation for myocardial revascularization. J. Thorac. Cardiovas. Surg. 80:242 (1980).

23. Hicks, H.C., Mowbray, A.G. \& Yhap, E.O. Cardiovascular effects of Catecholamine Responses to High Dose Fentanyl $-\mathrm{O}_{2}$ for Induction of Anesthesia in Patients with Ischemic Coronary Artery Disease. Anesth. Analg. 60: $563(1981)$

24. Levine, F.L., Philbin, D.M., Kono, K., CogGins, C.H., EMERSON, C.W., AUteN, W.G. \& BUCKLEY, M.J. Plasma Vasopressin levels and urinary sodium excretion during cardiopulmonary bypass with and without pulsatile flow. Ann. of Thor. Surg. 32: 63 (1981).

25. Comstock, M.K., Scamman, F.L., Carter, J.G., MoYeIs, J.R. \& Stevens, W.C. Rigidity and Hypercarbia on Fentanyl $-\mathrm{O}_{2}$ Induction. ASA Abstracts 51: S28 (1979)

26. MCClain, D.A. \& Hug, C.C. Intravenous Fentanyl Kinetics. Clinical Pharmac. Ther. 28: 106 (1980).

27. Stoeckel, H., Hengstmann, J.H. \& SchuttKER J. Pharmackinetics of Fentanyl as a possible explaination for recurrence of respiratory depression. Br. J. Anaesth. 51: 741 (1979).

28. Mummaneni, M., RaO, T.L.K. \& Montoya, A. Awareness and recall with high-dose fentanyl oxygen anaesthesia. Anesth. Analg. 59: 948 (1980).

29. HiLGENBERG, J.C. Intraoperative awareness during high-dose Fentanyl-Oxygen anaesthesia. Anesthesiology 54: 341 (1981).

\section{RÉSUME}

Les modifications hémodynamiques et celles de la vasopressine ont été observées chez douze patients de sexe masculin au cours de pontages aorto-coronariens effectués sous anesthésie au fentanyl-oxygène, le fentanyl étant administré à des doses de 75 à $100 \mu \mathrm{g} \cdot \mathrm{kg}^{-1}$. Les mesures étaient prises durant l'induction de l'anesthésie, à la stemotomie, durant la circulation extracorporelle, après la pompe et en post-opératoire. Une étude comparative parallèle a été menée chez douze autres patients anesthésiés cette fois à la 
morphine $\left(0.05 \mathrm{mg} \cdot \mathrm{kg}^{-1}\right)$ et ventilés avec un mélange de protoxyde d'azote et d'oxygène additionné de 0.5 pour cent d'halothane.

Parmi les modifications hémodynamiques significatives observées on souligne une augmentation de la pression artérielle moyenne après la sternotomie chez les patients anesthésiés au fentanyl, l'accélération de la fréquence cardiaque chez les patients des deux groupes, l'élévation de la résistance vasculaire périphérique après la stemotomie chez les malades du groupe anesthésié à l'halothane et, enfin, une diminution de l'index de travail d'éjection ventriculaire gauche chez les patients des deux groupes à la suite de l'induction de l'anesthésie, de la circulation extracorporelle et au cours de la phase post-opératoire immédiate.

Le taux de la vasopressine plasmatique se sont élevés au cours de la circulation extracorporelle chez les patients des deux groupes pour retourner vers les valeurs initiales après la C.E.C. Le sodium et l'osmolalité plasmatique en sont pas modifiés de façon significative alors que l'excrétion urinaire du sodium et du potassium s'élevait à mesure que progressait l'intervention.

On a trouvé une corrélation positive entre la pression artérielle moyenne et le taux de vasopressine seulement chez les malades endormis à l'halothane. La résistance vasculaire périphérique présentait une corrélation avec le taux de la vasopressine chez les patients des deux groupes.

Les réponses à la vasopressine ont ćté scmblables dans les deux groupes, avec des élévations significatives mais légères des valeurs de base au cours de la circulation extracorperelle. L'Anesthésie au fentanyl-oxygène n'a pas produit des conditions hémodynamiques stables chez 8 des 12 patients qui ont reçu cette forme d'anesthésie. 